\title{
Folic acid and breast cancer risk
}

\author{
Katarzyna Durda ${ }^{1 *}$, Katrzyna Jaworska-Bieniek ${ }^{1,2}$, Krzysztof Kąklewski ${ }^{1}$, Jan Lubiński ${ }^{1}$, Anna Jakubowska \\ From Annual Conference on Hereditary Cancers 2012 \\ Szczecin, Poland. 30-31 August 2012
}

Recent studies indicate that the selected micro-and macro-elements and vitamins may significantly influence the risk of cancer. Folic acid is a vitamin B which plays an important role in several processes in organism. Folates are important cofactors in the transfer and utilization of one-carbon-groups and play a key role in the remethylation of methionine thus providing essential methyl groups for numerous biological reactions. Furthermore, folates donate one-carbon units in the process of DNA-biosynthesis with implications for the regulation of gene expression, transcription, chromatine structure, genomic repair and genomic stability. Deficiency of folic acid has been reported to be associated with numerous disorders, including heart disease, stroke and cancers.

The MTHFR gene produces a key enzyme in folate metabolism which catalyses the reactions essential for nucleotide biosynthesis and DNA methylation.

The aim of study was to analyze an association of folic acid concentrations and genetic variants in the MTHFR gene with breast cancer risk in patients with BRCA1 mutation.

Study group consisted of 155 breast cancer patients and 155 healthy women from the paired control group matched to cases by year of birth, cancer family history, adnexectomy, smoking. From all individuals blood sample was collected and from cancer cases was taken before treatment. Folic acid concentration was quantitatively measured in blood plasma by HPLC chromatography (Flexar HPLC, Perkin Elmer). Two functional SNPs in the MTHFR gene, $677 \mathrm{C}>\mathrm{T}$ (rs1801133) and $1298 \mathrm{~A}>\mathrm{C}$ (rs1801131), both associated with reduced enzyme activity, have been tested by TaqMan on LightCycler 480.(Roche Diagnostic). Individuals were divided into four quartiles depending on folic acid concentration and number of cases and controls in each quartile was compared. Analysis

${ }^{1}$ International Hereditary Cancer Centre, Department of Genetics and

Pathology, Pomeranian Medical University, Szczecin, Poland

Full list of author information is available at the end of the article was made depending on menopausal status defined as $\leq$ 50 and $>50$ years old.

In a group of $>50$ years old, individuals classified in the first quartile $(<17,35 \mu \mathrm{mol} / \mathrm{l})$ had a lower risk of breast cancer than patients with higher folate level. Whereas in a group of $\leq 50$ years old, individuals classified in the 3 quartile $(24,35-31,88 \mu \mathrm{mol} / \mathrm{l})$ had a significantly lower risk of breast cancer than those with folate level between $32,02-54,42 \mu \mathrm{mol} / \mathrm{l}$. Analysis of correlation between the level of folic acid and genetic variants $677 \mathrm{C} / \mathrm{T}$ and 1298 $\mathrm{A} / \mathrm{C}$ in the MTHFR gene performed in 2 groups $(>50$ and $\leq 50$ years) revealed:

- for carriers of $1298 \mathrm{nCC}$ and $\leq 50$ years old significantly lower risk of breast cancer in individuals classified between $16,6-31,88 \mu \mathrm{mol} / \mathrm{l}$ in comparison to patients with lower and higher folate level.

- for carriers of $677 \mathrm{CC}$ and $\leq 50$ years old lower risk of breast cancer in individuals classified between 19,86$32,02 \mu \mathrm{mol} / \mathrm{l}$ than patients with lower and higher folate level.

- for carriers of $677 \mathrm{nCC}$ and $\leq 50$ years old significantly lower risk of breast cancer in individuals classified between $5,94-14,8 \mu \mathrm{mol} / \mathrm{l}$ in comparison to patients with higher folate level.

- for carriers of 1298 AA and $>50$ years old lower risk of breast cancer in individuals classified in the first quartile $(<18,6 \mu \mathrm{mol} / \mathrm{l})$ in comparison to patients with higher folate level.

- for carriers of $1298 \mathrm{nCC}$ and $>50$ years old lower risk of breast cancer in individuals classified in the first quartile $(<17,11 \mu \mathrm{mol} / \mathrm{l})$ in comparison to patients with higher folate level.

- for carriers of $677 \mathrm{CC}$ and $>50$ years old lower risk of breast cancer in individuals classified in the first quartile $(<18,62 \mu \mathrm{mol} / \mathrm{l})$ in comparison to patients with higher folate level.

- for carriers of $677 \mathrm{nCC}$ and $>50$ years old lower risk of breast cancer in individuals classified in the first 
quartile $(<17,1 \mu \mathrm{mol} / \mathrm{l})$ in comparison to patients with higher folate level.

We can conclude that concentration of folic acid in the range of $18-32 \mu \mathrm{mol} / \mathrm{l}$ is associated with lower risk of breast cancer for women $\leq 50$ years, with the possible exception for $677 \mathrm{nCC}(\mathrm{CT}+\mathrm{TT})$ where the lower risk of breast cancer is classified between 5,94-14,8 $\mu \mathrm{mol} / \mathrm{l}$.

Concentration of folic acid lower than $17 \mu \mathrm{mol} / \mathrm{l}$ is associated with lower risk of breast cancer for women $>50$ years.

\section{Author details}

${ }^{1}$ International Hereditary Cancer Centre, Department of Genetics and Pathology, Pomeranian Medical University, Szczecin, Poland. ${ }^{2}$ Postgraduate School of Molecular Medicine, Warsaw Medical University, Warsaw, Poland.

Published: 10 December 2012
Submit your next manuscript to BioMed Central and take full advantage of:

- Convenient online submission

- Thorough peer review

- No space constraints or color figure charges

- Immediate publication on acceptance

- Inclusion in PubMed, CAS, Scopus and Google Scholar

- Research which is freely available for redistribution

Submit your manuscript at www.biomedcentral.com/submit
C Biomed Central 